EREM 77/3

Journal of Environmental Research, Engineering and Management Vol. 77 / No. 4 / 2021 pp. 33-47

DOI 10.5755/j01.erem.77.4.29184
Contribution of Community Resilience to City's Livability within the Framework of Sustainable Development
Accepted after revision 2021/11

\title{
Contribution of Community Resilience to City's Livability within the Framework of Sustainable Development
}

\section{Surjono*, Adipandang Yudono}

Faculty of Engineering and Centre of Environmental Studies, University of Brawijaya, Indonesia

\section{Deni A. Setyono, Jasmine C Putri}

Faculty of Engineering Brawijaya University, Indonesia

\section{*Corresponding authors: surjono@ub.ac.id}

Lessons learned from the crisis in Indonesia prove that the concept of community resilience, together with community-based development, significantly affects the ability to fight against the crisis at the local and community levels. In addition to improving urban livability, today's urban development in Indonesia must also struggle to overcome various pressures due to natural disasters. Community resilience is considered a bottom-up solution to address these problems. This study aims to see how community resilience affects settlements' livability in Malang City, one of Indonesia's medium-sized cities. This research also analyses the relationship between resilience and livability variables to formulate prescriptive development strategies. The research used quantitative analysis by compiling and selecting data from secondary and primary sources to formulate indicators and variables of the proposed model. Descriptive analysis and structural equation modelling were conducted using SEM-PLS. The model built from this research shows that community resilience is the main factor that shapes livability in Malang City, indicated by social life, urban environment, and economy. Important variables forming community resilience are population vulnerability, physical infrastructure, and environmental infrastructure.

Keywords: livability, settlement, resilience, community, SEM-PLS. 


\section{Introduction}

Goal 11 of the SDGs is to make cities and human settlements inclusive, safe, resilient, and sustainable. This statement implies stages of a human settlement's quality from inclusive to sustainable cities. The priority is to create inclusive cities and human settlements by ensuring access for all citizens and promoting safety and resilience. Finally, the ultimate goal is to achieve sustainability, which means reconciling humans with nature and themselves (Duran et al., 2015). Furthermore, Urban Agenda and the Healthy City movements have supported this goal (Alderton et al., 2019). The challenge of each stage of the continuous process toward sustainable cities and human settlements is to improve the city's livability and the quality of life from the global level to the individual level (Estévez-Mauriz et al., 2017).

The linkage between a city's resilience and livability has unique strengths and characters; therefore, formulating livability variables that fit the local context is essential. Well-known global ranking media, such as the Economist Intelligence Unit (EIU), the Mercer Livability Index, and Forbes, have published global city's livability ranking. The EIU conducts annual assessments of 140 global capital cities. A recent review of those cities placed Vienna first (Berkes et al., 2008). The EIU, as well as Forbes, uses data provided by Mercer consulting company. Forbes exclusively evaluates American cities. Meanwhile, the OECD Better Life Index (OECD BLI) exclusively measures cities in the OECD countries. However, there is limited literature related to what constitutes livability from the perspective of low and middle-income countries (LMICs). An example of livability indicators from the perspective of LMICs is proposed by Alderton et al. (2019), who promote 24 indicators of urban livability for Bangkok's context. The 24 indicators are classified into 3 groups of priority: immediate action indicators, medium-term action indicators, and long-term action indicators. Malaysia has also developed urban indicators, namely the Malaysian Urban Indicator Network (MURNInet). It addresses 11 sectors of urban development. The MURNInet deals with general urban sustainability but does not focus on livability as a specific term (Islam et al., 2010).

The Indonesian Planner Association (IAP) has formulated livability indices in assessing the Most Livable City Index (MLCl) in Indonesia. The association started to assess the MLCl in Indonesia in 2009 and 2011 and every 3 years afterwards. The last published assessment was $\mathrm{MLCl}$ 2017. The $\mathrm{MLCl}$ bases its rank on seven variables: availability of basic needs, public and social facilities, public space, safety and security, environmental quality, social-economic and cultural infrastructures, and community participation. Indonesian $\mathrm{MLCl}$ uses the community's perception for its scoring system. MLCl 2017 assessment ranked Malang City at the $11^{\text {th }}$ place with a value of 63.5 , which was a decrease from its rank in 2014. Based on 4 $\mathrm{MLCl}$ assessments since 2009, the IAP classified that the majority of big cities (cities with more than one million inhabitants) in Indonesia are below the livable city category or cannot be included in the sustainable city category.

The current burden of the Malang City Government to enhance livability is getting heavier because, with limited resources, it still has to solve many natural disasters during the Covid-19 pandemic. Following the development of recent literature about resilience and learning from the economic crisis that hit Indonesia in the 1990s, which proves that the resilient community can survive and bounce back, we argue that bottom-up community resilience development can enhance the city livability. In the last 5 years, community resilience has become an interesting topic (Fan and Lyu, 2021). The resilience of the rural/village community is also an increasingly growing concept in developing social capital (McManus et al., 2012; Sarah, 2013). This study is limited and focused on the issue of community resilience and livability at the urban village (sub-district) level. The community resilience variables are related to survival and adaptation components. We hypothesize that the stronger the resilience, the better the livability. Therefore, this study aims to see the relationship between resilience 
and livability by raising the case in Malang City (a city designed by Thomas Karsten during the Dutch colonial period as a livable city). Variables and indicators related to resilience and livability are also elaborated.

\section{Theoretical Background}

Recent discussions on urban sustainability often relate to resilience, and city resilience often starts from community resilience (Long et al., 2010). Community resilience also has a reasonably close relationship with the level of community participation in settlement development (Vidianti et al., 2020). Resilience and sustainability are often overlapped because they have similarities, even though both are different in reality (Marchese et al., 2018). Sustainability broadly links social, economic, and environmental dimensions within both intragenerational and intergenerational scopes. Several authors promote additional dimensions such as institution (Elobeid, 2012), and culture (Taufen, 2014), and several other authors and institutions place humans as the fourth pillar of sustainable development. The term resilience itself is a learner's process of adapting to cope with specific changes and uncertainties, combining various types of knowledge, and creating an opportunity to deal with these changes and uncertainties (Berkes et al., 2008). One form of successful settlement development is how the community resilience is part of a social system where society consists of elements that have been systematically arranged with specific relationship patterns such as family, economic, government, religious, educational, and social relationship patterns. A settlement's ability to form community resilience is seen through preservation and development based on 5 elements: social, human, economic, physical, and environmental (Islam et al., 2010).

Table 1. Compilation of dimensions of urban livability

\begin{tabular}{|c|c|c|c|}
\hline \multirow{2}{*}{ Authors } & \multicolumn{3}{|c|}{ Dimensions } \\
\hline & Economy & Social & Environment \\
\hline National Research Council (2002) & Economy & Social life & Urban environment \\
\hline $\begin{array}{l}\text { Saitluanga (2014) } \\
\text { Norman (2012) }\end{array}$ & $\begin{array}{l}\text { Economy } \\
\text { Self-efficacy } \\
\text { Self-regulation }\end{array}$ & $\begin{array}{l}\text { Social } \\
\text { Household } \\
\text { Social capital }\end{array}$ & $\begin{array}{l}\text { Socioeconomic environment } \\
\text { Accessibility } \\
\text { Enabling infrastructure }\end{array}$ \\
\hline Pampanga et al. (2015) & $\begin{array}{l}\text { Business governance and } \\
\text { related infrastructure } \\
\text { Urban housing }\end{array}$ & $\begin{array}{l}\text { Urban safety and crime } \\
\text { Public health services }\end{array}$ & $\begin{array}{l}\text { Transportation and mobility } \\
\text { Climate change adaptation }\end{array}$ \\
\hline $\begin{array}{l}\text { Valcárcel-Aguiar, Murias, and } \\
\text { Rodríguez-González (2018) }\end{array}$ & Economic dimension & Social dimension & $\begin{array}{l}\text { Physical dimension } \\
\text { Natural dimension }\end{array}$ \\
\hline $\begin{array}{l}\text { Bangkok Metropolitan } \\
\text { Administration Report (Alderton } \\
\text { et al., 2019) }\end{array}$ & $\begin{array}{l}\text { Employment } \\
\text { Food } \\
\text { Housing }\end{array}$ & $\begin{array}{l}\text { Health and well-being } \\
\text { Social connected-ness } \\
\text { Social infrastructure }\end{array}$ & $\begin{array}{l}\text { Amenity } \\
\text { Environmental management } \\
\text { Public open space } \\
\text { Transport }\end{array}$ \\
\hline
\end{tabular}

Dimensions of livability, derived from sustainable development dimensions, comprise 3 interrelated spheres of social life: the economy, social well-being, and the environment (National Research Council,
2002). Furthermore, other authors expand social well-being and the environment into several dimensions such as household, accessibility, and socioeconomic environment (Saitluanga, 2014); urban housing, 
business governance and related infrastructure, urban safety, public health services, climate change adaptation, transportation, and mobility (Pampanga et al., 2015). Livability is measured from comprehensive indicators derived from the dimensions stated in Table 1, ranging from urban qualities to community and individual qualities. Community and individual qualities indicate the quality of life. Table 1 also shows that those indicators can be classified into 3 dimensions promoted by the National Research Council. These dimensions resemble sustainability dimensions. The term livability, therefore, to some extent, is interchangeable and conflated with sustainability. Other authors (Moser, 2009; Gazzola and Querci, 2017) have claimed that the quality of life, livability, is an instrument of sustainability. Table 1 summarizes the frameworks proposed by those authors.

\section{Method}

The livability of a city can be assessed based on several aspects. The most important aspects considered in the research consist of infrastructures, economy, urban environment, and social life. Information related to the livability index is obtained from observations of development and participation based on community perceptions. The level of community participation in settlement development has a reasonably close relationship with community resilience. Four elements form community resilience: population vulnerability, environmental infrastructure, social factors, and built-physical infrastructure (National Research Council, 2015).

Collecting data on the livability index and community resilience began with collecting (secondary) statistical data in all sub-districts from April to June 2020. Data from primary sources and interviews, taken from June to August 2020, i.e., chiefs of the neighbourhoods and head of villages (sub-districts), filled the gaps if the secondary data did not meet the required variable criteria. The collection of primary and secondary data and the analysis in this study follow the flow shown in Fig. 1.
Structural Equation Modeling - Partial Least Square (SEM-PLS) was used to determine the relationship between livability and community resilience variables. SEM-PLS is a multivariate analysis capable of simultaneously examining the relationship between complex variables, both recursive and non-recursive. SEM can also simultaneously test structural model (relationship between independent and dependent variables), regression analysis concept, measurement model (relationship between indicators and latent variables), and factor analysis concept. The hypothetical model assumes that city livability is supported by community resilience and 4 livability factors (urban infrastructure, economy, urban environment, and social life). Our hypothesis also assumes 4 constructs that form community resilience: population vulnerability, social factors, environment infrastructure, and physical infrastructure. Indicators of community resilience and livability are shown in Table 2, while Fig. 2 shows the hypothetical model of the relationship between variables in this study. We assume that resilience and 4 latent formative variables (urban infrastructures, economy, urban environment, and social life) form livability. Resilience is formed by 4 formative latent variables: population vulnerability, social factors, environmental infrastructures, and physical infrastructures. Several indicators reflect each latent variable. These indicators were actually measured from the 57 sub-districts in Malang City.

Fig. 1. Research flow diagram

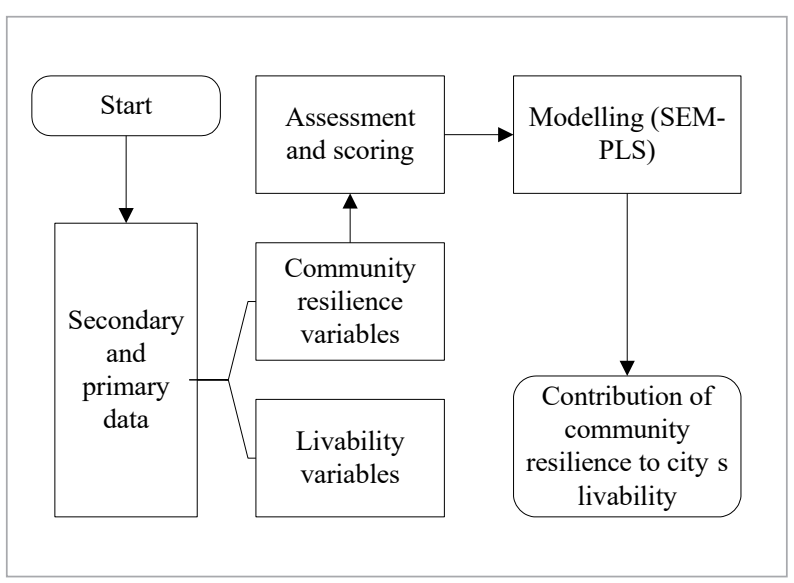


Table 2. Variables and indicators of community resilience and city livability

\begin{tabular}{|c|c|c|c|}
\hline \multicolumn{2}{|c|}{ Community resilience indicators } & \multicolumn{2}{|c|}{ City livability indicators } \\
\hline \multirow{4}{*}{$\begin{array}{l}\text { Population } \\
\text { vulnerability }\end{array}$} & Health issues (Phi) & \multirow[t]{6}{*}{ Urban infrastructure } & Clean water (Icw) \\
\hline & Marginal community (Pma) & & Educational facilities (lef) \\
\hline & Mobility (Pmo) & & Electricity (lel) \\
\hline & Sosial economic status (Pses) & & Heath facilities (Ihf) \\
\hline \multirow[t]{6}{*}{ Social factors } & Social capital (Sca) & & Road condition (Iro) \\
\hline & Culture (Scu) & & Transportation (Itr) \\
\hline & Education (Sed) & \multirow[t]{2}{*}{ Economy } & Job (Ejo) \\
\hline & Financial structure (Sfs) & & Business environment (lb) \\
\hline & Governance (Sgo) & \multirow[t]{4}{*}{ Urban environment } & Cleanliness (Ucl) \\
\hline & Workforce (Swf) & & Green space (Ugs) \\
\hline \multirow{2}{*}{$\begin{array}{l}\text { Environmental } \\
\text { infrastructure }\end{array}$} & Clean water (lcw) & & Planning (Upl) \\
\hline & Electricity (lel) & & Pollution (Upo) \\
\hline \multirow{4}{*}{$\begin{array}{l}\text { Physical } \\
\text { infrastructure }\end{array}$} & Business (lb) & \multirow[t]{4}{*}{ Social life } & Public space (Sps) \\
\hline & Emergency response facilities (lerf) & & Security (Sse) \\
\hline & Health facilities (Ihf) & & Information and public services (Sips) \\
\hline & Roads and bridges (Iro) & & Recreation facilities (Srf) \\
\hline
\end{tabular}

Fig. 2. Hypothetical model of the relationship between variables

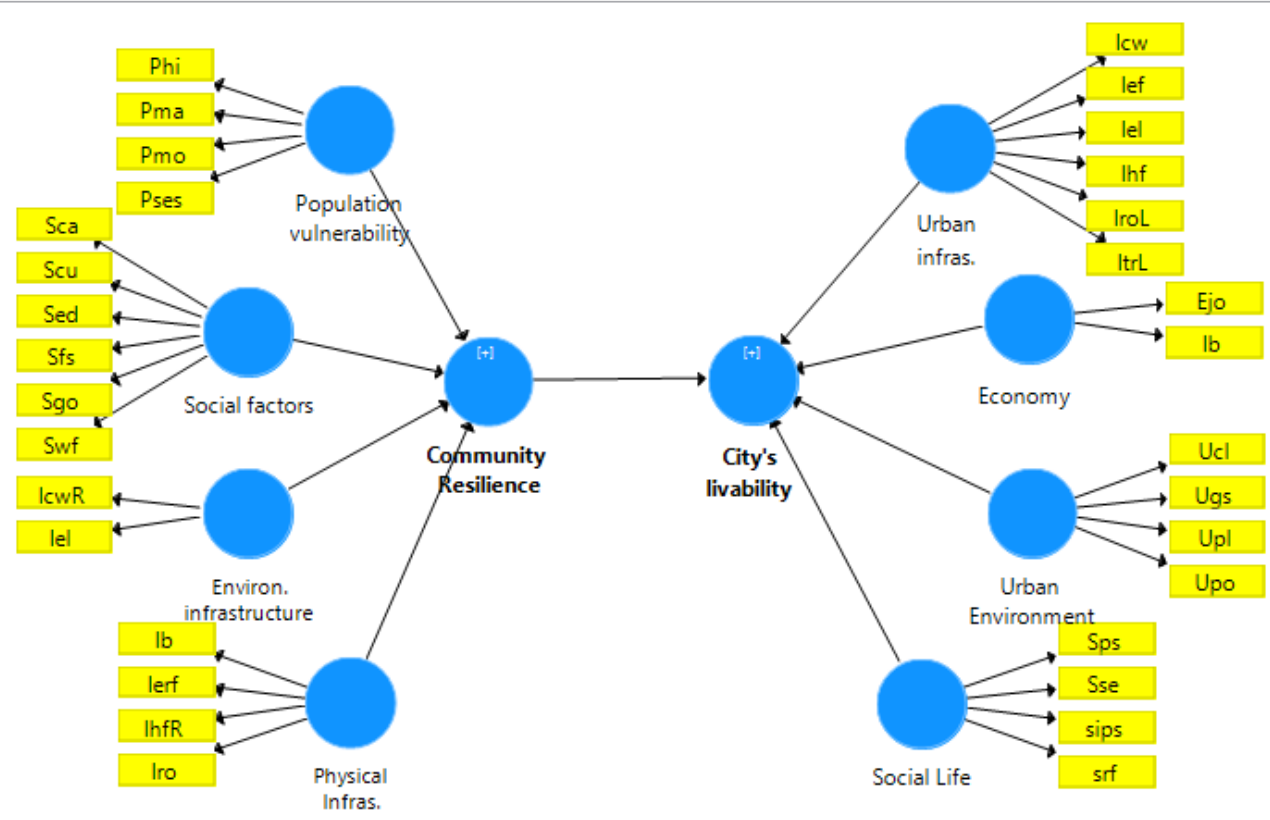




\section{Results and Discussion}

Observation and collection of primary and secondary data provide community resilience and livability indicators of 57 sub-districts in Malang City. SEM-PLS formulates the relationship between latent variables (endogenous) and indicators (exogenous). Several indicators assign to livability as well as community resilience. In SEM-PLS, each indicator must be assigned to whether livability or resilience variables. Indicators that are excluded in the analysis process are indicators that have the same value for all sub-districts, for example, telecommunications, because wireless telecommunications facilities cover all sub-districts. After reduction was made to be reliable and valid, the indicators for community resilience and livability were calculated. The next step was to look at the validity and reliability between the latent variables and their respective indicators. The 3 requirements used in this study are the Cronbach alpha above 0.5 , composite reliability above 0.7 , and average variance extracted (AVE) above 0.5. After iterating several times, we find that infrastructures fit as the indicators of environmental and physical infrastructures that form community resilience. Clean water becomes the only indicator of environmental infrastructure since electricity is uniformly distributed in all sub-districts. Selected indicators for physical infrastructure are infrastructures for health, education, business, and transportation, while road condition was omitted in the bootstrapping process. Another variable of community resilience, i.e., population vulnerability, was also modified to include 3 indicators, while the social factor variable was moved since its indicators fit as livability's indicators. Three omitted indicators of social factors were social capital, governance, and culture. The data of these 3 indicators were uniform at the urban village (sub-district) level. These findings confirm that resilience and liveability are interchangeable (Hamad, 2019).

The final path model for livability has several modifications from its first hypothetical model. Indicators of social life include education (knowledge), financial structures, and workforces. The urban environment only comprises two indicators: urban greenspace and pollution. Two indicators of urban environment did not change from the initial model: job and business. Other indicators, i.e., urban cleanliness, urban planning, and 4 indicators of social life, were omitted by the model since they did not meet one of validity and reliability requirements.

The final iteration shows that the valid indicators included in the model for community resilience (CR) from the aspect (latent variable) of population vulnerability are the following: marginal community (Pma), mobility (Pmo), and socioeconomic status (Pses);

Table 3. Variables and indicators for structural analysis

\begin{tabular}{l|l|l}
\multicolumn{1}{c|}{ Variables } & \multicolumn{1}{c}{ Indicators } & Codes \\
\hline City's livability - (L): & Jobs & Ejo \\
\hline \multirow{2}{*}{\begin{tabular}{l} 
Economy \\
\cline { 2 - 3 }
\end{tabular}} & $\begin{array}{l}\text { Business } \\
\text { environment }\end{array}$ & Ib \\
\hline $\begin{array}{l}\text { Urban planning and urban } \\
\text { environment }\end{array}$ & Greenspace & Ugs \\
\hline Social life & Pollution & Upo \\
\hline & Education & Sed \\
\cline { 2 - 3 } & Financial structures & Sfs \\
\cline { 2 - 3 } & Workforces & Swf \\
\hline
\end{tabular}

Community resilience (CR):

\begin{tabular}{l|l|l}
\hline Population vulnerability & Marginal community & Pma \\
\hline & Mobility & Pmo \\
\hline $\begin{array}{l}\text { Socio-economic } \\
\text { status } \\
\text { infrastructure }\end{array}$ & Clean water & Pses \\
\hline $\begin{array}{l}\text { Built physical } \\
\text { infrastructure }\end{array}$ & $\begin{array}{l}\text { Health and education } \\
\text { facilities }\end{array}$ & $\mathrm{IhfR}$ \\
\hline & $\begin{array}{l}\text { Transportasi } \\
\text { (transportation) }\end{array}$ & $\mathrm{Itr}$ \\
\hline & Business & $\mathrm{Ib}$ \\
\hline
\end{tabular}

Relationship of community resilience to livability (CR to L):

\begin{tabular}{l|l|l}
\hline City's livability $(\mathrm{L})$ & & \\
\hline Community resilience (CR) & & \\
\hline
\end{tabular}


environmental infrastructure is clean water (IcwR); and physical infrastructure aspects are business infrastructure (Ib), health infrastructure (IhfR) and transportation (ItrL). In the same way, the valid indicators included in the model for city's livability ( $L$ ) from the aspect of the economy are job (Ejo) and business environment (Ib); from the aspect of the urban environment are green space (Ugs) and pollution (Upo); and from the aspect of the social life are education (Sed), financial structure (Sfs) and workforce/labour (Swf). Table 3 describes variables and indicators of livability and community resilience calculated in SEM-PLS.

\section{Elaboration of Community Resilience Indicators}

There are 3 variables of community resilience: population vulnerability, environmental infrastructure, and physical infrastructure. The structural model generated these 3 variables based on data from 57 sub-districts. Community resilience and social vulnerability are two concepts that are significantly related, but their relationship is rarely empirically evaluated (Bergstrand et al., 2014). Their study showed that the least resilient counties (administrative or political subdivision of a state) in the United States tended to be the most vulnerable. Our study aims to test the relationship of the two concepts in urban village (sub-district) scales in a medium-sized city (Malang) of a developing country. The second variable, environmental infrastructures, plays a vital role in developing community resilience.

\section{a. Population vulnerability}

Likert's ordinal scale in this study can be divided into scores 1 and 2 to show below performance (poor and fair), while scores 3 and 4 indicate good and excellent performance. There are 7 sub-districts in Malang City that show good resilience in population vulnerability variable (good to excellent in marginal population indicator, socioeconomic status, and good in population mobility, no excellent score (4) in population mobility): Arjosari, Blimbing, Kidul Dalem, Klojen, Purwodadi, Polowijen, and Kauman. These 7 sub-districts have better performance in population vulnerability variables because they are nodes of Malang City urban structures such as Blimbing and Klojen. Arjosari is the regional transportation hub in Malang, while Purwodadi and Polowijen is the location of many new real estate developments. Slums and squatters are not found in these sub-districts. These data show that the other 50 sub-districts, or $88 \%$, tend to be underperforming (Table 4).

Table 4. Population vulnerability indicators that indicate "good" performance

\begin{tabular}{l|c|c|c}
\hline Sub-districts & $\begin{array}{c}\text { Marginal } \\
\text { population }\end{array}$ & $\begin{array}{c}\text { Socio-economic } \\
\text { status }\end{array}$ & $\begin{array}{c}\text { Population } \\
\text { mobility }\end{array}$ \\
\hline Arjosari & 4 & 4 & 3 \\
\hline Polowijen & 4 & 4 & 3 \\
\hline Kauman & 4 & 4 & 3 \\
\hline Purwodadi & 4 & 4 & 3 \\
\hline Klojen & 3 & 3 & 3 \\
\hline Kidul Dalem & 3 & 3 & 3 \\
\hline Blimbing & 3 & 3 & 3 \\
\hline
\end{tabular}

The performances in each indicator are described as follows.

\section{a.1 Marginal population (Pma)}

Community resilience is strongly influenced by the population quality, primarily because of the vulnerability faced by marginalized populations (Pma). This study does not identify social marginalities but rather highlights economic margins. The data used was the presentation of low-income people in the sub-district (kelurahan). The 3 most vulnerable sub-districts were Bumiayu Sub-district (61\% were low-income households), Tanjungrejo (56\%), and Tasikmadu (50\%). Poor settlements are found in Bumiayu and Tanjungrejo where most of the basic livelihoods of the population are farmers. These 3 sub-districts are rural to urban transition. Meanwhile, the best sub-districts (with the least percentage) were Sumbersari, Arjosari, Kesatrian, and Merjosari (Fig. 3). 
Fig. 3. Distribution of population vulnerability: (marginal population/ Pma) in Malang City

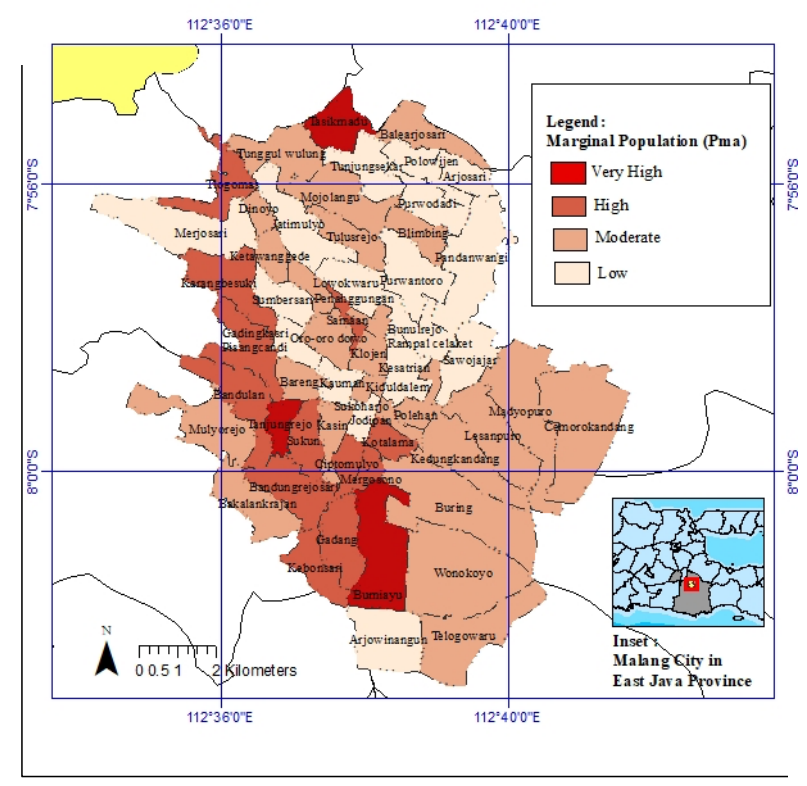

\section{a.2 Socioeconomic status (Pses)}

The socioeconomic status (Pses) has the opposite pattern to Pma. The smaller the Pma, the better Pses tends to be, and vice versa. The indicator of socioeconomic status is limited to a specific item, namely the distribution of the percentage of people above the poverty line (households with upper-middle-income) in a sub-district. Eighteen sub-districts (32\%) are categorized as good since more than $80 \%$ of their population are not poor. On the other hand, there are 3 sub-districts (5\%) with more than $50 \%$ of their population classified as poor. The other sub-districts are classified as moderate (between $51 \%$ to $80 \%$ of the non-poor). The pattern of sub-districts performance on Pses shows the same pattern with Pma.

\section{a.3 Population mobility (Pmo)}

Population mobility in this study is seen from the availability of transportation modes (public transportation routes) and access to transportation nodes (terminals, stations, airports) and the distance to arterial roads. Urban mobility in Malang can only be grouped into criterion 1/poor (38 sub-districts), criterion 2 /moderate (12 sub-districts), and criterion 3/ good (7 sub-districts). None of them can be grouped into criterion 4/excellent. The respondents perceived most that good quality of public transport is unavailable. Public transport in the city area tends to be replaced by online-based transportation (online taxi car and taxi bike).

\section{b. Environmental infrastructure variable has only one indicator, namely availability of clean water (IcWR)}

The availability of clean water infrastructure is seen from the percentage of the Local Water Company access availability in each sub-district in Malang City. Based on the analysis result, piped clean water service has covered $100 \%$ of areas of 9 sub-districts. In general, all sub-districts have been supplied by clean water services. The lowest coverage was $85.58 \%$, and there are only 4 sub-districts with clean water coverage between $85-90 \%$ of the residents. This indicator shows that provision of clean water in all sub-districts is relatively good. However, piped drinking water is still very limited to a few sub-districts. The distribution of piped drinking water should be the focus of the Local Government and Local Water Enterprise.

\section{c. Built physical infrastructure}

The variable of physical infrastructure comprises 3 indicators: transportation infrastructure (Itr), business infrastructure (Ib), and health service infrastructure (IhfR). There are 4 sub-districts that show good performances in the 3 indicators. The best sub-district is Kauman, then followed by Klojen, Purwodadi and Polowijen (Table 5). The performances in these 4 sub-districts indicate good resilience in physical infrastructures. Kauman and Klojen are located at the city's heart, while Polowijen and Purwodadi are locations of new real estate development. The other 53 sub-districts may have good performance in one of two items only.

Table 5. Built physical infrastructure indicators that indicate "good" performance

\begin{tabular}{l|c|c|c}
\hline Sub-districts & Transportation & Business & Health services \\
\hline Kauman & 3 & 4 & 4 \\
\hline Klojen & 3 & 4 & 3 \\
\hline Purwodadi & 3 & 3 & 4 \\
\hline Polowijen & 3 & 3 & 3 \\
\hline
\end{tabular}


Performances in each indicator are as follows.

\section{c.1 Transportation infrastructure (Itr)}

Transportation infrastructure was obtained from the availability of types and public transportation modes that serve each sub-district in Malang. The analysis resulted in only 7 urban villages with good transportation infrastructure, namely Polowijen, Arjosari, Purwodadi, Blimbing, Klojen, Kauman, and Kidul Dalem sub-districts. Twelve sub-districts were moderate, and 38 sub-districts were still lacking.

\section{c.2 Business infrastructures (Ib)}

The business infrastructure indicator was obtained from the monthly turnover of income for Low-Income Communities (LIC). The results of the analysis show that 14 sub-districts have low LIC turnover. Four sub-districts were moderate, 24 sub-districts were in good criteria, and 15 sub-districts were very good. Sub-districts that have good LIC turnover are at strategic locations that are traversed by urban transportation networks.

\section{c.3 Health serlvice facilities (IhfR)}

The health service facility (IhfR) indicator was obtained from the type and number of health facilities available, consisting of a maternity hospital, polyclinics, local community public health centres, auxiliary of local community public health centres, and pharmacies. The results found that 5 sub-districts still had inadequate health service facilities, 19 were moderate, 21 were good, and 12 sub-districts were already very good.

The general findings of all indicators in 3 variables of community resilience in all sub-districts show that sub-districts that have excellent (score about 4) community resilience are Kauman, Purwodadi, Polowijen, and Arjosari. Twenty-four sub-districts are relatively good (score about 3) (see Fig. 4 and Table 6). The discussion confirms Zautra et al.'s (2008) statement that substantial improvement in the field of transportation and communication and development of peri-urban areas improves community resilience, particularly for the population vulnerability variable, as shown by findings in the discussion. The improvement of economic indicators strengthens the robustness of the community (Long et al., 2010). Better provision of urban infrastructures, in general, increases community resilience in terms of the robustness and resourcefulness of the physical capital (Atreya and Kunreuther, 2016).
Fig. 4. Aggregated rate of community resilience in 57 sub-districts in Malang City

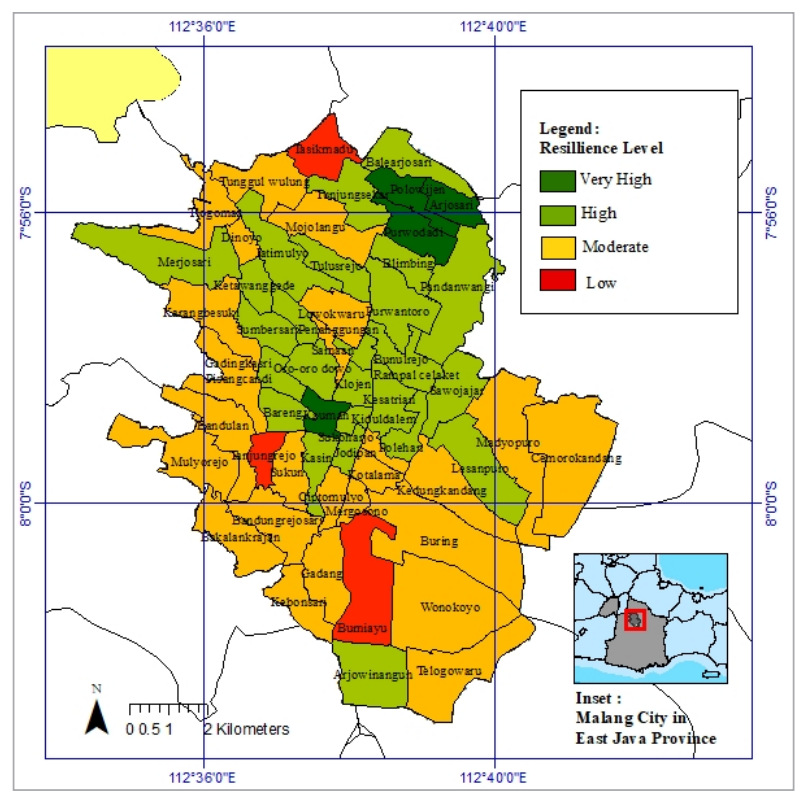

Table 6. Resilience score of sub-districts with excellent and good performance

\begin{tabular}{l|l|l|l}
\hline Sub-districts & $\begin{array}{c}\text { Resilience } \\
\text { score }\end{array}$ & Sub-districts & $\begin{array}{c}\text { Resilience } \\
\text { score }\end{array}$ \\
\hline Kauman & 3.67 & Sukoharjo & 2.88 \\
\hline Purwodadi & 3.57 & Merjosari & 2.86 \\
\hline Polowijen & 3.55 & Kesatrian & 2.83 \\
\hline Arjosari & 3.53 & Tunjungsekar & 2.82 \\
\hline Purwantoro & 3.34 & Sawojajar & 2.79 \\
\hline Bunulrejo & 3.25 & Kasin & 2.74 \\
\hline Lowokwaru & 3.19 & Penangggungan & 2.74 \\
\hline Klojen & 3.06 & Oro-oro Dowo & 2.72 \\
\hline Jatimulyo & 3.00 & Rampal Celaket & 2.72 \\
\hline Blimbing & 3.00 & Tulusrejo & 2.66 \\
\hline Pandanwangi & 3.00 & Balearjosari & 2.64 \\
\hline Kidul Dalem & 2.97 & Bareng & 2.64 \\
\hline Sumbersari & 2.91 & Ketawanggede & 2.56 \\
\hline Gadingkasri & 2.89 & Polehan & 2.53 \\
\hline Arjowinangun & 2.88 & & \\
\hline & & &
\end{tabular}




\section{Elaboration of Livability Indicators}

The final path model shows that livability in Malang City's sub-districts has 3 reflective variables: social life, economy, and urban environment. The social life variable has 3 reflective indicators, while the economy and urban environment have 2 reflective indicators each.

\section{a. Social life}

The social life variable has 3 indicators: workforce, financial structure, and educational level. Blimbing is a sub-district that shows good performance in these 3 indicators. The second rank is Bunulrejo sub-district. The elaboration of sub-districts' performance in each variable is as follows.

\section{a.1 Workforce indicator (Swf)}

The labour indicator or workforce was obtained from the total number of livelihoods divided by households in each sub-district in Malang City. Based on the analysis results, the following 3 sub-districts have a high labour level: Arjosari, Blimbing, Sumbersari, and Bunulrejo. One sub-district was good, 14 sub-districts were moderate, and 39 sub-districts were still lacking. The workforce indicator was taken from the percentage of unemployment to the total workforce. The unemployment rate in the 57 sub-districts ranged from $3.01 \%$ to $3.21 \%$. Since the distribution was clustered into 4 categories, the unemployment rate over $3.15 \%$ was considered lacking. There are about $68 \%$ of the sub-districts in this category.

\section{a.2 Financial structure indicator (Sfs)}

Financial structure indicators show finance sources that the community can use to support a family's lives, including income, expenses, savings, accounts payable, and aid funds. The analysis shows that 13 sub-districts had low financial services, 4 sub-districts were moderate, 24 sub-districts were good, while 16 sub-districts had excellent financial services. Based on the low-income community's perspective, $70 \%$ of the sub-districts already have good to excellent financial services such as access to a) traditional markets, b) trade and service centres, c) activity management units for revolving funds, and d) cooperative institutions. Sub-districts with low financial services are only $23 \%$; they only have 2 to 3 financial institutions in each district.

\section{a.3 Education level indicator (Sed)}

The education level indicator was obtained from the number of people who have taken various education levels from elementary school (SD) to undergraduate. Seven sub-districts were identified to have a higher education level: Balearjosari, Blimbing, Merjosari, Mojolangu, Oro-oro Dowo, Purwantoro, and Tlogowaru. Meanwhile, there are still 7 sub-districts with low education levels, namely Arjowinangun, Bandungrejosari, Kesatrian, Sukoharjo, Sukun, Tanjungrejo, and Tasikmadu. The main item of education indicator (Sed) is years of schooling or the percentage of the population who have graduated from higher education institutions. The 7 sub-districts have more than $25 \%$ of their population graduated from universities, while the other 7 sub-districts have less than 10\%.

\section{b. Economy: based on the model, the economic variable has 2 indicators: jobs (Ejo) and business environment (Ib)}

\section{b.1 Jobs indicator (Ejo)}

The Ejo indicator was calculated from the ratio between the number of jobs and the number of households. Three sub-districts have a good performance, namely Arjosari (96,97\%), Blimbing (96.99\%), and Sumbersari $(96,976 \%)$. In contrast, there are still 7 sub-districts that have low performance, namely Bakalan Krajan (96.808\%), Dinoyo (96.807\%), Arjowinangun (96.806\%), Merjosari (96.802\%), Jatimulyo (96.798\%), Tlogowaru (96.793\%), and Wonokoyo (96.793\%). The result of this indicator is quite similar to the workforce indicator of social life.

\section{b.2 Business environment (Ib)}

The business environment indicator for livability was measured from monthly sales volume of each sub-district. The monthly sales volume is divided into 3 groups which then was assessed on a scale of 1 to 3 , i.e., a value of 1 if the sales volume is < IDR 5,000,000 (equal to USD 351.77), a value of 2 if the volume is IDR $5,000,000$ to IDR $15,000,000$, and a value of 3 if the volume is $>$ IDR $15,000,000$. The value of the sales volume grouping is then multiplied by the number of businesses to obtain the average value. Based on the average value, 57 sub-districts in Malang can be 
Fig. 5. Distribution of jobs / the employment rate (Ejo) in Malang City
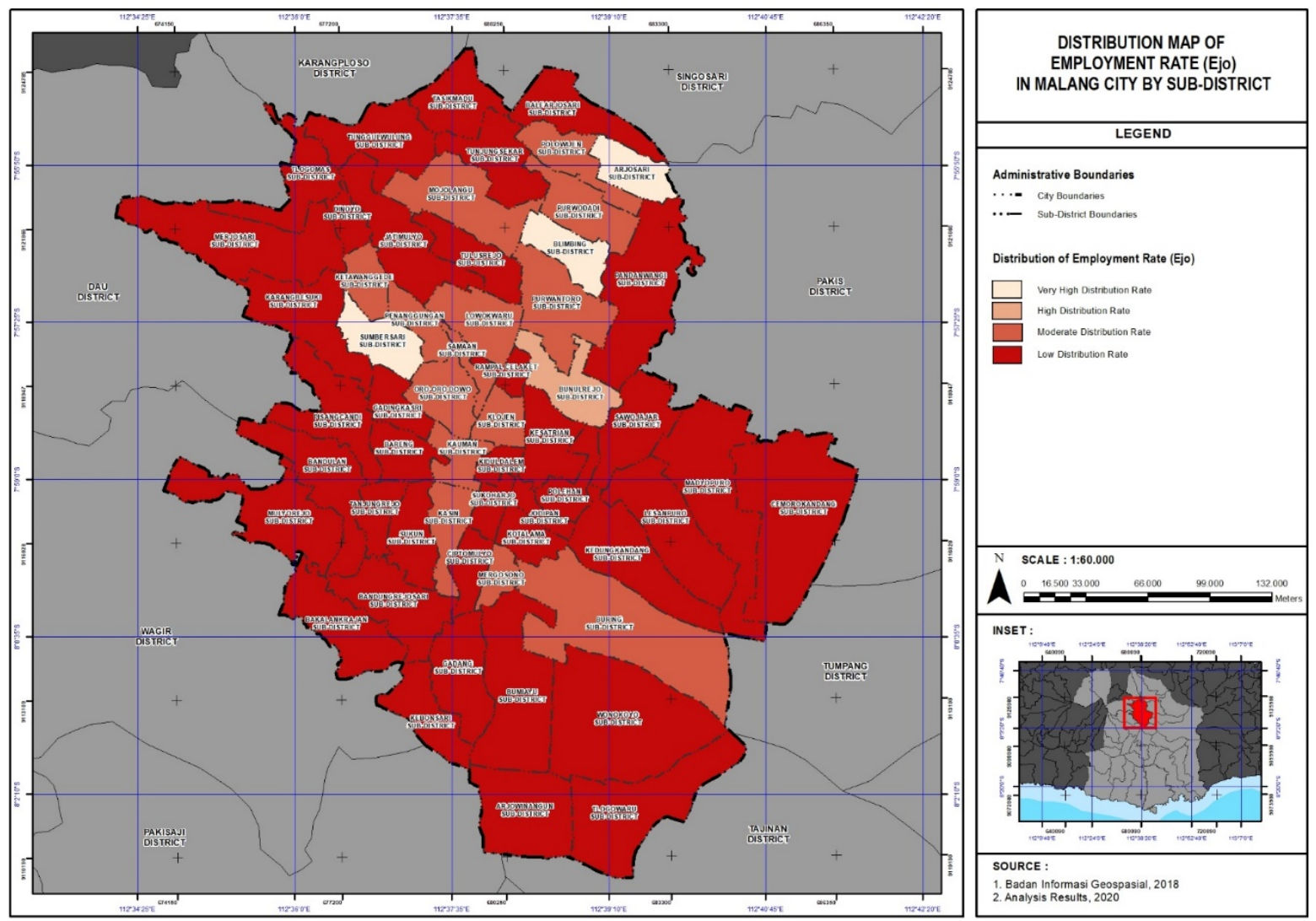

grouped into 4 categories ( 1 = bad to 4 = excellent). Fourteen sub-districts are included in category 1, 4 sub-districts in category 2, 24 sub-districts in category 3 , and 15 sub-districts in category 4.

\section{c. Urban environment}

The urban environment variable has 2 indicators: urban population and green space. Ten sub-districts (18\%) can be classified as sub-districts with a "good urban environment". These sub-districts have low performance in other variables and exemplify the character of peri-urban areas that have more green areas and less pollution (Table 7). It is crucial to maintain the green space of these sub-districts while improving other livability variables.

The performance of the 2 indicators is elaborated in the following discussion.
Table 7. Performance in the urban environment variable

\begin{tabular}{l|c|c}
\multicolumn{1}{c|}{ Sub-districts } & Pollution & Green space \\
\hline Wonokoyo & 4 & 4 \\
\hline Tlogowaru & 4 & 4 \\
\hline Madyopuro & 4 & 4 \\
\hline Buring & 4 & 3 \\
\hline Cemorokandang & 4 & 4 \\
\hline Arjowinangun & 4 & 3 \\
\hline Kedungkandang & 3 & 4 \\
\hline Lesanpuro & 3 & 4 \\
\hline Mulyorejo & 3 & 4 \\
\hline Kesatrian & 3 & 3 \\
\hline
\end{tabular}




\section{c.1 Urban pollution (Upo)}

This indicator was based on the assumption that sub-districts with a large area of green open spaces and far from arterial roads and collectors have lower pollution levels. Based on these criteria, 10 sub-districts have high pollution levels (Balearjosari, Bareng, Bumiayu, Jodipan, Kotalama, Mergosono, Samaan, Sukoharjo, Sukun, and Tasikmadu). Twenty-nine sub-districts were moderate, 4 sub-districts were acceptable, and 14 others were already good. This condition shows that less than one-third of the 57 sub-districts are considered "moderate to good" in reducing urban pollution. In general, the air quality index (AQI) in Malang fluctuated between good (50 or less) and moderate (51-100 US AQI) (Thach et al., 2018). The quality of rainwater was ideal (pH 5.6-6). However, surface water quality, with $\mathrm{BOD}_{5}, \mathrm{COD}$ exceeds the threshold (BMKG, 2021; Sholichin, 2012).

\section{c.2 Greenspace indicator (Ugs)}

Urban green space (Ugs) was a percentage of urban green areas in each sub-district. Indonesian spatial planning act (Spatial Planning Act No. 26 of 2007) urges all local governments in Indonesia to provide public green open space for at least $20 \%$ of the administrative area. The analysis identifies only 7 sub-districts that provide at least $20 \%$ of the urban areas as green areas (Arjowinangun, Buring, Cemorokandang, Madyopuro, Merjosari, Tlogowaru, Wonokoyo). Eight sub-districts provide about $15 \%$, and 16 sub-districts have about $10 \%$. The rest 26 sub-districts have only about $5 \%$ green areas. This situation shows that $88 \%$ of all sub-districts in Malang City cannot fulfil the requirements. At the city level, public green open spaces are only about $5 \%$.

Based on the findings and discussion of livability variables and indicators, 3 sub-districts have good livability, i.e., Blimbing, Arjosari, and Sumbersari. The livability scores of these 3 sub-districts are 3.11,2.85, and 2.53, respectively. No sub-district has an excellent livability score of reflective indicators (Table 8 ). This finding is interesting since these 3 sub-districts are neither CBD nor peri-urban of Malang City. Blimbing is a node of the development area of North Malang, Arjosari is the transportation hub in North Malang, while Sumbersari is part of the higher education district in Malang City.
Table 8. Livability score of sub-districts with good and fair performance

\begin{tabular}{l|c|l|c}
\hline \multicolumn{1}{|c|}{ Sub-districts } & $\begin{array}{c}\text { Livability } \\
\text { score }\end{array}$ & \multicolumn{1}{|c}{ Sub-districts } & $\begin{array}{c}\text { Livability } \\
\text { score }\end{array}$ \\
\hline Blimbing & 3.11 & Klojen & 2.21 \\
\hline Arjosari & 2.85 & Lowokwaru & 2.21 \\
\hline Sumbersari & 2.53 & Mojolangu & 2.16 \\
\hline Oro-Oro Dowo & 2.48 & Kebonsari & 2.04 \\
\hline Purwantoro & 2.47 & Ketawanggede & 2.03 \\
\hline Bunulrejo & 2.35 & Purwodadi & 2.02 \\
\hline Kauman & 2.35 & Dinoyo & 2.02 \\
\hline Kasin & 2.34 & Samaan & 2.01 \\
\hline
\end{tabular}

\section{Structural Model of Community Resilience and Livability}

The path model (Fig. 6) shows that three formative latent variables primarily determine community resilience in the study area in order from the most influential: population vulnerability, physical infrastructure, and environmental infrastructure. These three variables form the community resilience, and the community resilience (with other factors (about 5.8\%) that are not discussed in this research) strongly (94.2\%) forms the livability in Malang City.

This finding is based on community resilience (CR) and livability $(L)$ determination coefficient. The $R$ square adjusted values of community resilience and livability are 0.953 and 0.942 , respectively. The most significant community resilience component in Malang is population vulnerability, followed by physical infrastructure and environmental infrastructure. Of the 57 sub-districts in Malang, only 4 have high community resilience. Those sub-districts are Kauman, Purwodadi, Polowijen, and Arjosari. Kauman sub-district has the least low-income community (LIC) population (17.27\%), good population mobility and transportation indicators, excellent business infrastructures, health facilities, and clean water provision. Meanwhile, the sub-districts which have good livability performance are Blimbing, Arjosari, and Sumbersari. Among these 3 sub-districts, Arjosari is the only sub-district with 
the best performance in community resilience and urban livability. Urban livability is reflected by (reflective indicators) from the most influential: social life, economy, and urban environment. This finding confirms similar research that neighbourhood relations influence urban livability (Lee, 2021). The finding also confirms that other factors may contribute to livability in the sub-districts, particularly factors that influence the urban environment variable. Two items of the urban environment variable - pollution and urban greenspace - need to be addressed by the government. These items are the domain of public policy interventions rather than the community responses.
The finding also recommends that the local government must give more attention and finance to the 3 weakest sub-districts, namely Tasikmadu, Bumiayu, and Tanjungrejo sub-districts. Strengthening community resilience, particularly the 3 items in the population vulnerability variable, improves livability performance, particularly in the social life and economic variables. Community investment and engagement are essential to improve population indicators (Pfefferbaum et al., 2015). Improvement of livability is reflected by social life and economic variables; then the betterment of these 2 variables finally would also result in a better urban environment.

Fig. 6. Community resilience and livability model for Malang City

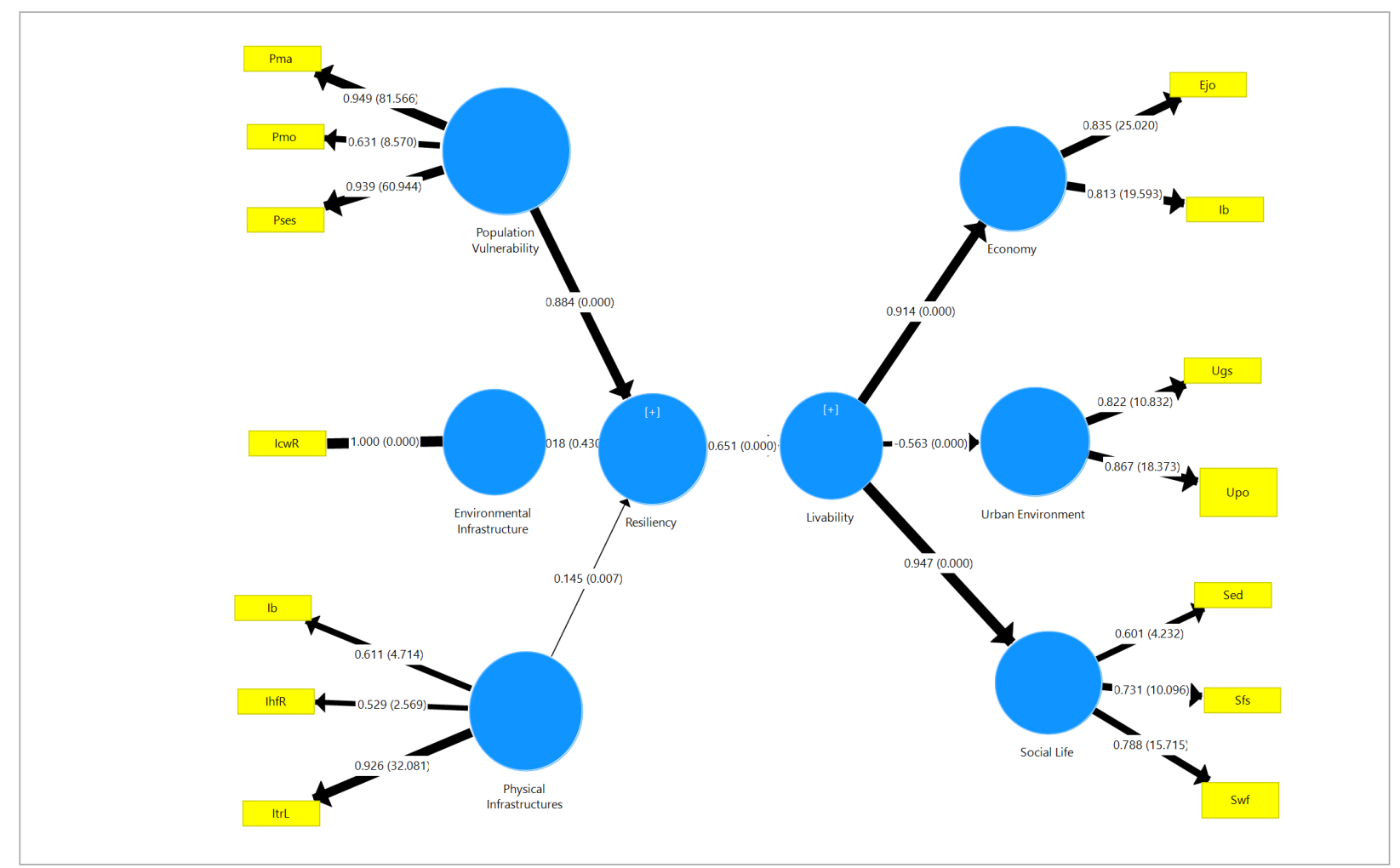

\section{Conclusion}

The conclusion is based on valid and reliable data on community resilience variables and the livability index. Furthermore, the analysis was carried out for the hierarchical structure of the paths and their load factor (loading factor) to produce the following conclusions.
Livability in Malang City is reflected in 3 main aspects: economy, urban environment, and social life. The significant economic indicators were employment and business infrastructure. The urban environment quality was mainly reflected in pollution and the presence 
of open space, while employment, financial services, and level of education reflect the social life aspect. Meanwhile, 3 essential aspects, namely population vulnerability, physical infrastructure, and environmental infrastructure, form community resilience. Population vulnerability was reflected by the percentage of a marginalized population, population mobilization, and socioeconomic status. The infrastructure consists of transportation, health and education, business, and provision of clean water.

The resulting model concludes that community resilience is one of the significant components in making cities livable. In the modelling process, the literature review found that many community resilience indicators are also livability indicators. This structural model proves that livability is also greatly influenced by community resilience. This model also supports the bottom-up development paradigm that builds cities through strengthening community development. The development of peri-urban areas is also crucial in strengthening community resilience that improves livability. Closing the resilience gap among sub-districts in all variables is essential to achieve better livability.

\section{References}

Alderton, A., Davern, M., Nitvimol, K., Butterworth, I., Higgs, C., Ryan, E., and Badland, H. (2019). What is the meaning of urban liveability for a city in a low-to-middle-income country? Contextualising liveability for Bangkok, Thailand. Globalization and Health, 15(1), 51. https://doi.org/10.1186/s12992-019-0484-8

Atreya, A., and Kunreuther, H. C. (2016). Measuring Community Resilience: The Role of the Community Rating System (CRS). SSRN, June(13), 1-38. https://doi.org/10.2139/ssrn.2788230

Bergstrand, K., Mayer, B., Brumback, B., and Zhang, Y. (2014). Assessing the Relationship Between Social Vulnerability and Community Resilience to Hazards. Social Indicators Research, 122(2), 391-409.https://doi.org/10.1007/s11205-014-0698-3

Berkes, F., Colding, J., and Folke, C. (2008). Navigating social-ecological systems: building resilience for complexity and change. In F. Berkes, J. Colding, and C. Folke (Eds.), Cambridge University Press (3rd ed.). https://doi.org/10.1016/j.biocon.2004.01.010

BMKG. (2021). Prakiraan Cuaca (Weather Forecast). Retrieved February 15, 2021, from https://www.bmkg.go.id/cuaca/prakiraan-cuaca-indonesia.bmkg?Prov=12andNamaProv=Jawa Timur
These development processes ultimately become the trigger for general city-scale development.

Several important issues for further research that are identified by the findings and limitations inherent in this research are related to mediator and predictor variables and their indicators. Based on the determination coefficient, the findings indicate there are still few mediators or predictor variables and their indicators of livability that are not incorporated in this research. It is also interesting why several indicators promoted in the literature, such as urban cleanliness and planning, are omitted variables. Are these differences related to the spatial level (city - district - sub district/village)? Or are they influenced by mindset or lifestyle? This condition directs further researches with more comprehensive variables and indicators that constitute urban livability at the village, local, and regional levels. Since livability, to some extent, is perceptional, it is also interesting to compare and contrast livability indicators from different localities and cultures. It is also essential that further research addresses more variables related to the evolution component (transformative behaviour changes) of resilience.

Duran, D. C., Gogan, L. M., Artene, A., and Duran, V. (2015). The Components of Sustainable Development - A Possible Approach. Procedia Economics and Finance, 26, 806 - 811. ttps:// doi.org/10.1016/S2212-5671(15)00849-7

Elobeid, D. (2012). The Role of Institutions in Sustainable Development: The Experience of Sudan Economy. OIDA International Journal of Sustainable Development, 4(5), 53-68.

Estévez-Mauriz, L., Fonseca, J. A., Forgaci, C., and Björling, N. (2017). The livability of spaces: Performance and/or resilience? Reflections on the effects of spatial heterogeneity in transport and energy systems and the implications on urban environmental quality. International Journal of Sustainable Built Environment, 6(1), 1-8. https://doi.org/10.1016/j.ijsbe.2016.10.001

Fan, Y., and Lyu, X. (2021). Exploring Two Decades of Research in Community Resilience: A Content Analysis Across the International Literature. Psychology Research and Behavior Management, 14, 1643-1654. https://doi.org/10.2147/PRBM.S329829

Gazzola, P., and Querci, E. (2017). The Connection Between the Quality of Life and Sustainable Ecological Development. European Scientific Journal, 361-375. Retrieved from https://eujournal.org/index.php/esj/article/view/9212 
Hamad, S. (2019). Creating Sustainable, Liveable, and Resilient Communities. Retrieved November 1, 2021, from The Sustainabilist website: https://thesustainabilist.ae/creating-sustainable-liveable-and-resilient-communities/

Islam, T., Merrell, W., and Seitz, W. (2010). Galveston Futures: Developing a disaster resilient community. Journal of Geography and Regional Planning.

Lee, K. Y. (2021). Factors influencing urban livability in Seoul, Korea: Urban environmental satisfaction and neighborhood relations. Social Sciences, 10(4). https://doi.org/10.3390/socsci10040138

Long, P., Armstrong, N., Perrin, K., Parker, W. M., and Hidek, M. (2010). Building Resilient Communities: A Preliminary Framework for Assessment. Homeland Security Affairs, 6(3), 1-23.

Marchese, D., Reynolds, E., Bates, M. E., Morgan, H., Clark, S. S., and Linkov, I. (2018). Resilience and sustainability: Similarities and differences in environmental management applications. Science of the Total Environment, 613-614(September), 12751283. https://doi.org/10.1016/j.scitotenv.2017.09.086

McManus, P., Walmsley, J., Argent, N., Baum, S., Bourke, L., Martin, J., ... Sorensen, T. (2012). Rural Community and Rural Resilience: What is important to farmers in keeping their country towns alive? Journal of Rural Studies - J RURAL STUD, 28. https://doi.org/10.1016/j.jrurstud.2011.09.003

Moser, G. (2009). Quality of life and sustainability: Toward person-environment congruity. Journal of Environmental Psychology. https://doi.org/10.1016/j.jenvp.2009.02.002

National Research Council. (2002). Community and Quality of Life: Data Needs for Informed Decision Making. https://doi. org/10.17226/10262

National Research Council. (2015). Developing a Framework for Measuring Community Resilience. In Developing a Framework for Measuring Community Resilience. https://doi. org/10.17226/20672

Norman, W. (2012). Adapting to change: the role of community resilience. Retrieved from https://www.youngfoundation.org/ publications/adapting-to-change-the-role-of-community-resilience/

Pampanga, D., Majid, M., and Johar, F. (2015). Appropriate Urban Livability Indicators for Metropolitan Johor, Malaysia via
Expert-Stakeholder Approach: a Delphi technique. International Journal of Built Environment and Sustainability, 2. https://doi. org/10.11113/ijbes.v2.n4.98

Pfefferbaum, R., Pfefferbaum, B., Nitiema, P., Houston, J. B., and Horn, R. (2015). Assessing Community Resilience: An Application of the Expanded CART Survey Instrument With Affiliated Volunteer Responders. American Behavioral Scientist, 59 , 181-199. https://doi.org/10.1177/0002764214550295

Saitluanga, B. l. (2014). Spatial Pattern of Urban Livability in Himalayan Region: A Case of Aizawl City, India. Social Indicators Research, 117. https://doi.org/10.1007/s11205-013-0362-3

Sarah, S. (2013). Enhancing the analysis of rural community resilience: Evidence from community land ownership. Journal of Rural Studies, 31, 36-46. https://doi.org/10.1016/j.jrurstud.2013.02.003

Sholichin, M. (2012). Field Investigation of Groundwater Contamination from Solid Waste Landfill in Malang, Indonesia. International Journal of Civil and Environmental Engineering, 12(2), 1-8.

Taufen, A. (2014). Urban Blue Space and "The Project of the Century": Doing Justice on the Seattle Waterfront and for Local Residents. Buildings, 4(4), 764-784. https://doi.org/10.3390/ buildings 4040764

Thach, T.-Q., Tsang, H., Cao, P., and Ho, L.-M. (2018). A novel method to construct an air quality index based on air pollution profiles. International Journal of Hygiene and Environmental Health, 221(1), 17-26. https://doi.org/10.1016/j. ijheh.2017.09.012

Valcárcel-Aguiar, B., Murias, P., and Rodríguez-González, D. (2018). Sustainable urban liveability: A practical proposal based on a composite indicator. Sustainability (Switzerland). https:// doi.org/10.3390/su11010086

Vidianti, R. A., Surjono, Nurwarsito, H., and Prayitno, G. (2020). Community Resilience and Sustainability Levels of Thematic Kampong in Malang City. https://doi.org/10.2991/assehr.k.201021.056

Zautra, A., Hall, J., and Murray, K. (2008). Community Development and Community Resilience: An Integrative Approach. Community Development, 39(3). https://doi. org/10.1080/15575330809489673 